\title{
The Legal Certainty and Protection of Foreign Investment Againsts Investment Practices in Indonesia
}

\author{
Januari Nasya Ayu Taduri \\ Faculty of Law, Universitas Negeri Semarang, Semarang, Central Java, Indonesia \\ Email: januari.nasyaayu2000@students.unnes.ac.id \\ ORCID Link: https://orcid.org/0000-0002-5297-4363
}

\begin{abstract}
Citation:
Taduri, J. N. A. (2021). The Legal Certainty and Protection of Foreign Investment Againsts Investment Practices in Indonesia. Lex Scientia Law Review, 5(1), 119-138, doi: https://doi.org/10.15294/lesrev.v5i1 .46286
\end{abstract}

\section{History of Article}

Received: April 10, 2021

Revised: May 14, 2021

Accepted: May 27, 2021

(C) The Author(s)

\section{(c) (i) (2)(2)}

This work is licensed under a Creative Commons Attribution-NonCommercialShareAlike 4.0 International License.

All writings published in this journal are personal views of the authors and do not represent the views of this journal and the author's affiliated institutions.

Lex Scientia Law Review published by Faculty of Law, Universitas Negeri Semarang, Indonesia in collaboration of UKM Lex Scientia. Published biannually every May and November.

\begin{abstract}
Foreign investment or well known as "Foreign Capital Investment" is one of the state's efforts to accelerate the pace of the Indonesian economy. So, it is not surprising that the Indonesian Government continues to carry out juridical reforms related to foreign investment. This renewal cannot be separated from the objective of providing certainty and guaranteeing legal protection for foreign investors, so that they can continue to carry out investment in the territory of the Republic of Indonesia. But the question that arises by the author, are the Indonesian laws and regulations sufficient to provide legal certainty in various aspects of investment, from licensing to dispute resolution? In response to this, this paper aims to further examine the legal certainty and protection of foreign investors in carrying out Foreign Direct Investment. The legal research method used is normative legal research through a statutory approach. In addition, this paper uses secondary legal data sources.
\end{abstract}

\section{KEYWORDS}

Foreign Direct Investment; Foreign Investment; Foreign Investors; Legal Certainty 


\section{INTRODUCTION}

Indonesia is a developing country located in Southeast Asia with a wealth of natural resources and a high number of human resources ${ }^{1}$. Based on data from the Ministry of Home Affairs, it is stated that the total population of Indonesia is $271,349,889$ people in $2020 .{ }^{2}$ Meanwhile, the total working age population will be 203.97 million in $2021 .^{3}$

On the other hand, the natural wealth owned by Indonesia is scattered in various sectors, which are located throughout the archipelago, such as: agriculture, plantation, mining, fishery and marine, to tourism due to its natural beauty. This is reinforced by the results of Prof.'s research. Dr. Jatna Supriatna, M.Sc as an expert in Conservation Biology and Ecology from the Faculty of Mathematics and Natural Sciences, University of Indonesia, who said that "there are still around $90 \%$ of Indonesia's natural wealth that has not been successfully explored". ${ }^{4}$ In other words, there are still many potential natural resources for community welfare that are not yet known by the wider community. Even though Indonesia has the potential for natural resources as well as human resources. However, the state is faced with problems related to a lack of capital to manage natural resources. Thus, Indonesia's economic growth is hampered. ${ }^{5}$

One of the ways that the government takes to get capital is through investment. The essence of investment activities refers to the aim of the Indonesian constitution to create public welfare, as well as the mandate of Article 33 (3) regarding natural resources that are contained to be used for the welfare of the Indonesian people. ${ }^{6}$

\footnotetext{
1 Widyawan and Partners, Linklaters., "Legal Guide to Investment in Indonesia", Widyawan and Partners, July 2014, accesed from https://widyawanpartners.com/english/pubs/Investing-inIndonesia.pdf.

2 Kompas Staff, "Provinsi dengan Jumlah Penduduk Terbanyak", Kompas, January 24 2021, accesed from https://money.kompas.com/read/2021/01/24/090600726/7-provinsi-dengan-jotal-pendudukterbanyak-di-

indonesia?page=all\#: :text=KKementerian\%20Dalam\%20Negeri\%20(MinistryofHomeAffairs) $\% 20$ stated,(number\% 20 population\% 20 Indonesia\% 202021).

${ }^{3}$ Badan Pusat Statistik, "Agustus 2020: Tingkat Pengangguran Terbuka (TPT) sebesar 7,07 persen", Badan Pusat Statistik, May 11 2020, accesed from https://www.bps.go.id/pressrelease/2020/11/05/1673/agustus-2020--tkala-pengunemploymentterbuka--tpt--sebesar-7-07-persen.html\#: : text =Total\% 20\%20work\%20\%20August, $\% 200 \% 2 \mathrm{C} 24 \%$ 20percent\%20points.

${ }^{4}$ Gloria, "Sembilan Puluh Persen Kekayaan Alam Indonesia Belum Dieksplorasi", Univeristas Gadjah Mada, July 17 2017, accesed from https://www.ugm.ac.id/id/berita/14277-sembilan-puluh-persenkekayaan-alam-indonesia-belum-dieksariasi.

${ }^{5}$ Devi Andani, "Tinjauan Hukum Investasi Dampak Judicial Review Undang-Undang Nomor 25 Tahun 2007 Tentang Penanaman Modal", Nurani Hukum : Jurnal Ilmu Hukum Volume 2 Number 2, 2019, p. 16.

${ }^{6}$ Article 33 paragraph 3. The 1945 Constitution.
} 
The investment chosen by the state is foreign investment. In short, foreign investment is defined as activities carried out by foreign investors by investing directly or indirectly into productive businesses with the aim of obtaining a return on initial capital. ${ }^{7}$ In Indonesia, foreign investment has existed since 1967, to be precise at the beginning of the new order which is regulated in The Act Number 1 of 1967 concerning Foreign Investment and has been renewed in The Act Number 25 of 2007 concerning Investment.

The objective of holding foreign investment is to accelerating national economic development. ${ }^{8}$ There are several benefits through foreign investment, such as: absorbers of Indonesian labor, increase foreign exchange, develop facilities and infrastructure, increase state tax revenues, and transfer knowledge and technology. ${ }^{9}$ Apart from the positive impact of foreign investment on capital receiving countries, investing countries also benefit from low wage costs for labor in developing countries.

Based on data from the Investment Coordinating Board, it is stated that, from 2015-2020, the percentage of Indonesian FDI has fluctuated. In 2018 the portion of FDI realization began to decline. In 2020, the total realization of FDI decreased by $8.1 \%$ yoy from last year. ${ }^{10}$ The same is stated by Bank Indonesia, that in 2020, Indonesia experienced a decline in international investment position at the third quarter. It is due to lower foreign financial liabilities and an increase in foreign financial assets. ${ }^{11}$

However, far from this, in 2012-2013 the Fraser Institute survey institute conducted research which showed that Indonesia was ranked 96th in terms of the attractiveness of global investment regulations. This is due to several factors, including: rapid changes in regulations, inconsistencies in regulations related to investment, bureaucratic transparency, corruption, convoluted business licensing processes, regulatory restrictions related to foreign

\footnotetext{
7 Nanci Yosepin Simbolon, et al., "Perlindungan Hukum Bagi Penanaman Modal Asing ( PMA) di Indonesia", Jurnal Darma Agung, Volume 28 Number 1, 2020, p. 65.

${ }^{8}$ Darrel R Johnson and Greita Anggraeni, Foreign Investment Review 2020, Law Business, London, 2020, p. 47.

9 Feibe Engeline Pijo and Isle Junita Melo, "Legal Study on Non-Commercial Risk Investment in Indonesia", Advances in Social Science, Education and Humanities Research, Number 473, 2020, p. 52.

${ }^{10}$ Tirta Citradi, "RI Masih Belum Ramah Investor Asing, Ini Buktinya", CNBC Indonesia News, September 09 2020, accesed from https://www.cnbcindonesia.com/news/20200904145710-4184465/ri-masih-belum-ramah-investor-asing-ini-buktinya.

${ }^{11}$ Hadijah Alaydrus, "BI: Posisi Investasi Asing di Indonesia Melambat di Kuartal III, Apa Sebabnya Ya?", Ekonomi Bisnis, January 22 2020, accessed from https://ekonomi.bisnis.com/read/20201223/9/1334622/bi-posisi-Investasi-asing-di-indonesiamelambat-di-kuartal-iii-apa-sebabnya-ya.
} 
investment, lack of access, facilities \& infrastructure in doing business and distrust of foreign countries in Indonesia's dispute settlement legal system. ${ }^{12}$ Not surprisingly, the inconsistency of regulations and investment restrictions in the investment sector affects the rights and protections of foreign investors as enshrined in the principles of the World Trade Organization (hereinafter as WTO).

Responding to this, the authors argue that the state should improve the national legal system that can provide protection for foreign investors in the form of legal certainty, in order to attract investors to invest in Indonesia. Moreover, foreign investors prefer countries with legal products that can guarantee risk-free business.

Thus, the authors are interested in further research related to the certainty and guarantee of legal protection of FDI practices for foreign investors in Indonesia.

The problem formulations that must be solved are as follows:

1. What are the laws and regulations relating to investment in Indonesia?

2. Have the laws and regulations related to investment provide certainty and guaranteed protection for foreign investors in Indonesia?

\section{METHOD}

In this paper, the author uses a qualitative research approach that is descriptive through a comprehensive analysis. While the legal research approach chosen is the statutory approach or statute approach. ${ }^{13}$ This approach aims to assist the author in conducting a review of statutory regulations, as well as solving legal issues which the author believes do not yet have comprehensive statutory provisions. ${ }^{14}$ Meanwhile, the type of legal research used is normative legal research or often called doctrinal law research. In this paper will examine various aspects of the problems in positive law related to the practice of Foreign Direct Investment by foreign investors in Indonesia. ${ }^{15}$ In addition, this journal article refers to secondary legal data sources which include the following: official documents, books, scientific journals, reports, and related laws and regulations. ${ }^{16}$

\footnotetext{
${ }^{12}$ Benny Hutahayan, et al., "Investor Protection in Mining Law in Indonesia", Journal of Critical Reviews, Volume 7, Number 13, 2020, p. 1.

${ }^{13}$ Peter Mahmud, Metode Penelitian Hukum, Prenadamedia Group, Jakarta, 2005, p. 174.

${ }^{14} \mathrm{Ibid}, \mathrm{p} .136$.

${ }^{15}$ Kornelius Benuf dan Muhamad Azhar, "Metodologi Penelitian Hukum sebagai Instrumen Mengurai Permasalahan Hukum Kontemporer", Jurnal Gema Keadilan, Volume 7 Number 1 p. 2324.

${ }^{16}$ Soerjono Soekonto, Pengantar Penelitian Hukum, University of Indonesia, Depok, 2015.
} 


\section{RESULT AND DISCUSSION}

\section{A. Foreign Direct Investment and the Rule of Law in Indonesia}

The word "investment" in statutory regulations is referred to as "investment" or is interpreted as "an investment activity that can be carried out by natural persons (natural persons) companies and organizations originating from within the country or abroad". ${ }^{17}$ In the investment process, capital can be invested in the form of cash, non-assets, equipment, expertise or intellectual property rights. ${ }^{18}$

Based on the investor's point of view, investment is divided into two. There are domestic investment and foreign investment. In simple terms, domestic investment is an investment activity carried out by investors from that country. Meanwhile, foreign investment is the practice of investing in which the capital comes from foreign citizens or is jointly with the destination country. In addition, according to the opinion of Muthucumaraswamy Sornarajah in his book entitled "The International Law on Foreign Investment", he explained that foreign investment is an act of transferring tangible and intangible assets from one country to the destination country and guaranteeing wealth under responsibility asset owner. ${ }^{19}$

In Indonesia, foreign investment plays a very important role in the country's development process. This statement was supported by the formation of regulations related to FI in Indonesia through The Act Number 1 of 1967 concerning Foreign Investment. ${ }^{20}$ These laws and regulations are the starting point for FI law in Indonesia with the purpose of providing legal certainty to carry out foreign investment practices in Indonesia.

The legal regulations related to FI in Indonesia have undergone several reforms and changes, including the following: 1) The Act Number 1 of 1967 concerning Foreign Investment, 2) The Act Number 11 of 1970, 3) The Act Number 25 of 2007 concerning Investment. In the latest regulations, both Foreign Investment and Domestic Investment are made into an integral part of the investment legislation. ${ }^{21}$

\footnotetext{
${ }^{17 D h a n i s w a r a ~ K ~ H a r j o n o, ~ H u k u m ~ I n v e s t a s i, ~ R a j a ~ G r a f i n d o ~ P e r s a d a, ~ J a k a r t a, ~ 2007, ~ p . ~ 30-31 . ~}$

${ }_{18}$ Ibid

${ }^{19} \mathrm{Ibid}$, Retrieved from Muthucumaraswamy Sornarajah, The International law on Foreign Investment, Cambridge University Press, Cambridge, 2004, p. 8.

${ }^{20}$ Petra Bunawan, "Foreign Investment in Indonesia the Legal Aspects under the New Indonesian Investment Law", Dialogica Iuridica, Volume 8 Number 2, 2017, p. 3.

${ }^{21}$ Acep Rohendi, "Prinsip Liberalisasi Perdagangan World Trade Organization", Padjadjaran Jurnal Ilmu Hukum, Volume 1, Number 2, 2014, p. 390.
} 
In the process of $F I$, the legal subject or investor is an individual foreign citizen, foreign business entity, foreign government. ${ }^{22}$ This has been confirmed in Article 1 point 6 of The Act No 20/2007. There are provisions related to the capital sharing system or joint venture between foreign and domestic investors, that foreign investors own a maximum of $95 \%$ of capital, while domestic investors control a minimum of $5 \%$ of capital. ${ }^{23}$

Based on macroeconomic science, FI can take two forms, as follows:

a) Direct investment. This is a form of investment made by building infrastructure, buying as a whole or by acquiring a company. Investors in this investment play an active role in managing the company and are directly responsible for losses. ${ }^{24}$

b) Indirect investment or often referred to as "Portfolio Investment". This investment is an investment process using securities, such as: bonds, stocks. In practice, investors do not actively participate in the management of the company, only providing capital in the form of money..$^{25}$

According to Kurniati, in her writing Determinants of FDI, she classifies Foreign Direct Investment in 2 forms, among others, as follows: a) Horizontal FDI or an investment activity by foreign investors by producing the same goods in several targeted countries. b) Vertical FDI or an investment activity initiated through the production of goods in the host country at an economic labour price which results from production will be given back to the parent country. ${ }^{26}$ In practice FDI can be formed as a result of mergers, acquisitions with a minimum of $10 \%$ of financial assets, joint ventures, mergers, or Greenfields or the formation of new units in the host country. ${ }^{27}$

Whereas in practice in Indonesia, Foreign Direct Investment is aimed at investment between the state or government, BUMN (State-Owned Corporation) or the private sector with foreign countries which can be carried out jointly through a cooperation agreement. There are several types of cooperation that can be done, such as: franchise and brand-use agreements,

\footnotetext{
${ }^{22}$ Article 1 number 6 . The Act Number 1 of 1967 concerning Foreign Investment.

${ }^{23}$ Agung Sudjati Winata, "Perlindungan Investor Asing dalam Kegiatan Penanaman Modal Asing dan Implikasinya Terhadap Negara", Adjudikasi : Jurnal Ilmu Hukum, Volume 2, Number 2, 2018, p. 129.

${ }^{24}$ Anita, "Jaminan Kepastian Hukum Berinvestasi Melalui Pendekatan Konsep Lawrence M Friedman Dalam Menghadapi ASEAN Economic Community (AEC)", Jurnal Res Justitia: Jurnal Ilmu Hukum, Volume 1, Number 1, 2021, p. 19.

${ }^{25} \mathrm{Ibid}$.

${ }^{26}$ Yati Kurniati, et al., "Determinants of FDI (Factors that Determine Foreign Direct Investment)", Bank Indonesia Working Paper, 2007, p. 16-17.

${ }^{27} \mathrm{Ibid}, \mathrm{p} .18$.
} 
management contracts, technical assistance contracts, joint venture agreements and built, operation and transfers. ${ }^{28}$

In Indonesia, Foreign investors can choose various sectors to invest in Indonesia. The available sectors are as follows: agriculture, forestry, marine $\mathcal{E}$ fisheries, energy $\mathcal{E}$ mineral resources, industry, defense $\mathcal{E}$ security, trade, public works, transportation, tourism $\mathcal{E}$ creative economy, finance, communication $\mathcal{E}$ informatics, education, employment, health and banking. ${ }^{29}$ However, in practice, FI cannot simply invest in Indonesia. This is because there are several commodities that are prohibited from investing in foreign and domestic investors. Business fields that are closed for investment are regulated in Article 12 (2) of the Investment Act which consists of war equipment, such as explosives, gunpowder or other weapons production, as well as other commodities regulated in the relevant regulations. ${ }^{30}$ There are special rules related to the negative list of investments. However, there are changes, from Presidential Regulation Number 44 of 2016 concerning List of Closed Business Sectors and Open Business Sectors with Requirements in the Investment Sector become Presidential Regulation Number 10 of 2021 concerning the Investment Sector. The regulation cuts several restrictions from the previous Presidential Regulation, which only leaves a few closed areas for investment, such as: gambling, cultivation and the narcotics industry class I, catching fish species in Appendix I CITES, utilization and collection of corals. ${ }^{31}$

Furthermore, the practice of foreign direct investment in Indonesia will relate to licensing and dispute resolution due to risks from investment. The regulations that form the basis of legal licensing and investment in Indonesia, are as follows:

a) Based on Articles 25 and 26 of The Act Number 25 of 2007 concerning Investment, it explains that investment companies will obtain investment permits with the provisions of the respective laws and regulations of the relevant agencies. ${ }^{32}$ In other words, the investment licensing process follows the rules of each agency in the target sector. Meanwhile, based on changes to simplification of licensing requirements, it is amended in

\footnotetext{
${ }^{28}$ Muhammad Akbar Riski, Kepastian Hukum Investasi Bagi Perusahaan Penanaman Modal Asing di Indonesia, Fakultas Hukum Univesitas Jember, Sripsi, 2018, p. 22.

29Presidential Regulation Number 44 of 2016 concerning List of Closed Business Sectors and Open Business Sectors with Requirements in the Investment Sector.

${ }^{30}$ Article 12 paragraph 1 . The Act Number 25 of 2007 concerning Investment.

${ }^{31}$ Muhammad Wildan, "Revisi Daftar Negatif Investasi, Pemerintah Rilis Draf Perpres Terbaru", DDTCNews, January 11 2021, accessed from https://news.ddtc.co.id/revisi-daftar-negatif-in Investasi-pemerintah-rilis-draf-perpres-terbaru-26876?page_y=2470.666748046875.

32 Article 25 and Article 26. The Act Number 25 of 2007 concerning Investment.
} 
The Act Number 11 of 2020 concerning Job Creation, which in essence implements risk-based licensing, simplifying basic requirements for business, sector and investment licensing. The risk-based application consists of low, medium and high levels. In addition, in Chapter X, Article 154 - Article 173 of the Job Creation Law regulates Central Government Investment and the Ease of National Strategic Projects which briefly form two main things. There are the establishment of a SWF (Sovereign Wealth Fund) Institution and the provision of land and permits by the government. ${ }^{33}$

b) Laws and regulations related to investment, especially Act No. 25 of 2007, have regulated the risk of disputes or conflicts between investors. Article 32 states that disputes that occur against domestic investment can be carried out through the initial stages of deliberation to reach consensus. However, if the problem cannot be resolved, then a litigation dispute settlement route can be taken through court or non-litigation through arbitration. Meanwhile, if foreign investors are involved, international arbitration settlement will be used. ${ }^{34}$

\section{B. Problems of Foreign Direct Investment Practices in Indonesia}

In early 2016, Joko Widodo as the President of the Republic Indonesia launched a plan to increase economic diplomacy. It aims to support Indonesia's economic growth through enhancing international trade and the foreign investment climate. ${ }^{35}$ The improvement of the investment climate is in line with the various programs that have been launched by ASEAN, including the following: 1) Free Trade Agreement (FTA) between ASEAN and partner countries, such as : ASEAN-China Free Trade Agreement which has been established since 2000. 2) ASEAN Comprehensive Investment Agreement since 2009 that has produced two products. There are Framework Agreement on the ASEAN Investment Area and ASEAN Agreement for the Promotion and Protection of Investment. ${ }^{36}$

In addition, Indonesia has great potential to attract foreign investors to invest here. This was conveyed by Nordea on its online page which mentions

${ }^{33}$ Muhammad Insa Ansari, "Omnibus Law Untuk Menata Regulasi Penanaman Modal”, Jurnal Rechtsvinding, Volume 9, Number 1, 2020, p. 9.

${ }^{34}$ Article 32. The Act Number 25 of 2007 concerning Investment.

${ }^{35}$ Aleksius Jemadu, et al., Kinerja Diplomasi Ekonomi: Evaluasi atas Perjanjian Perdagangan dan Investasi, Badan Pengkajian dan Pengembangan Kebijakan Kementerian Luar Negeri Republik Indonesia, Jakarta, 2016, p. 7.

${ }^{36}$ Resha Roshana Putri, et al., "Peringkat Arus Investasi Indonesia Dalam Kerangka ASEAN-China Free Trade Agreement (Perbandingan Dengan Singapura, Malaysia, Thailand dan Vietnam) Ditinjau Dari Prinsip Fair dan Equitable Treatment", Jurnal Hukum \& Pembangunan, Volume 48, Number 2, 2018, p. 276-277. 
some of the attractions and advantages of conducting FDI in Indonesia, including, as follows: 1) Indonesia has a large enough population of 270 million people and benefits companies from any country to do business. 2) abundant natural resources. 3) high biodiversity. 4) The development of the middle class is high. 5) The Good condition of banking and financial sectors. ${ }^{37}$

However, although there are various promising potentials for investing in Indonesia, it does not guarantee the high interest of foreign investors to invest their capital. Based on data from the ASEN Working Group on International Investment Strategy, in 2015 the inflow of foreign direct investment amounted to $\$ 75$ million and was 6th position in ASEAN, where the highest FDI was held by the Philippines with a total of $\$ 98$ million. ${ }^{38}$ The low inflow of FDI is influenced by a country's inflation rate. According to data released by the World Bank, from 1960 to 2019 Indonesia's total inflation was $44.6 \%$ with a minimum inflation of $3 \%$ in 2019 and a maximum of $1136 \%$ in 1966. ${ }^{39}$ Although, currently Indonesia's inflation rate is quite normal, around $3 \%$, it is still high compared to other countries in ASEAN, such as: Malaysia $(0.3 \%)$, Singapore (0.5) and Thailand (0.7) as of 2019.40

The low interest of foreign investors to invest in Indonesia is influenced by several factors, including the following:

a) Economic Factors

This factor is one of the most influential aspects in the development of investment in Indonesia. However, the condition of a country's economic stability cannot be separated from political conditions. If the political condition is unstable, it will have an impact on the decline in economic performance. As a result, investors are not interested in investing in the country. As for the aspects that affect the economy, well known as "monetary". ${ }^{41}$ In this case, each country will compete to form monetary policies that can create currency stability. ${ }^{42}$ Thus, monetary stability can attract foreign investors to make investments.

${ }^{37}$ Nordea, "Foreign direct investment (FDI) in Indonesia", Nordea Trade Portal, accessed from https://www.nordeatrade.com/en/explore-new-market/indonesia/investment.

${ }^{38}$ Rina Susanti, "Peran Pertumbuhan Ekonomi dan Inflasi Terhadap Kinerja Investasi Asing Langsung (FDI) DI Negara ASEAN", Journal of Residues Volume 2, Number 12, 2018, p. 62.

${ }^{39}$ The Global Economy, "Indonesia: Inflation", The Global Economy, accessed from https://www.theglobaleconomy.com/Indonesia/inflation/\#: :text=The\%20average\%20value\%20for\%20 Indonesia,on\%20countries\%20is\%200.0\%20percent.

${ }^{40}$ Bank Indonesia, Laju Inflasi di Beberapa Negara, Bank Indonesia, accessed from https://www.bi.go.id/seki/tabel/TABEL9_2.pdf.

${ }^{41}$ Dhaniswara K Harjono, Op.Cit., p. 9.

${ }^{42}$ Bank Indonesia, "Monetary",Bank Indonesia, accessed from https://www.bi.go.id/id/fungsiutama/moneter/default.aspx. 
b) Political Factors

The unstable political condition of a country greatly affects the business climate. As a result, the attractiveness of foreign investors to invest decreases. The political stability of a country is closely related to the policies of the laws and regulations made by the legislative body. Where in practice, the legislative body is chosen through a series of political processes, so that the making of legal rules is inseparable from the interests of the political elite. ${ }^{43}$

c) Legal Factors

Most foreign investors want a host country with a good trade record of law enforcement, low levels of corruption, transparency of all government policies, fair and efficient laws, and regulations that support smooth investment. ${ }^{44}$ Based on data from ICW (Indonesian Corruption Watch), it is stated that in 2020 there were around 196 corruption cases. ${ }^{45}$ Meanwhile, according to survey results from Transparency International issued the Corruption Perception Index 2020, where Indonesia was ranked 102nd out of 180 countries with 35 scores out of $100 .{ }^{46}$ This indicates that Indonesia is still a country with a fairly high level of corruption.

Apart from the factors that influence the rate of growth of foreign investment in Indonesia, there are also several problems with the practice of FDI in Indonesia, as follows:

a) Overlapping Legislation

From a legal point of view, the investment regulations in Indonesia (Act No. 25 of 2007) are interrelated and influenced by other laws, such as: the Minerba Law, the Electricity Law, the Land Management Law, the Regional Government Law, the Manpower Law. So it does not rule out disharmony between several laws and regulations. ${ }^{47}$ There are several examples of overlaps or inconsistencies in regulations related to investment in Indonesia, as follows:

\footnotetext{
${ }^{43}$ Hafid Zakariya, "Pengaruh Hukum dan Politik Terhadap Perkembangan Investasi Asing di Indonesia", Jurnal Serambi Hukum, Voluime 10, Number 2, 2016, p. 84.

${ }^{44}$ Dhaniswara K Harjono, Op.Cit., p. 10.

${ }^{45}$ Handoyo. "ICW menyebut ada 169 kasus korupsi sepanjang semester I 2020", Nasional Kontan, September 292020 accessed from https://nasional.kontan.co.id/news/icw-menyebut-ada-169-kasuskorupsi-sepanjang-semester-i-2020.

${ }^{46}$ Galuh Kartiko, et al., "Penerapan Omnibus Law di Bidang Investasi Sebagai Upaya Penyelesaian Regulasi Perizinan dan Harmonisasi Peraturan Perundang-Undangan.", Prosiding Seminar Nasional Multidisiplin Ilmu Universitas Asahan, 2020, p. 748.

${ }^{47}$ Agus Surachman, "Kritik Terhadap Undang-Undang Nomor 25 Tahun 2007 Tentang Penanaman Modal (Perspektif Teori Hukum)", Unifikasi: Jurnal Ilmu Hukum, 2018, p. 29.
} 
1) Based on Article 1 point 4 it has been explained that both foreign and domestic investment can be done in the form of a legal entity or an individual, but Article 5 (2) clearly states that foreign investors must be in the form of a limited liability company based on Indonesian law and be in Indonesian territory unless otherwise specified by law. ${ }^{48}$ So that the author can conclude that the two articles are inconsistent, giving rise to legal confusion.

2) In addition, there is an inconsistency between Article 3 letter $\mathrm{d}$, which states that foreign investment in Indonesia does not differentiate from country of origin and gives the same treatment. However, Article 6 paragraph 2 explains that the principle of equal treatment does not apply to foreign investors who have special rights in special agreements. ${ }^{49}$

According to the author's understanding, the issue of inconsistency and overlapping regulations related to investment greatly affects investor confidence in the Indonesian legal system, thus indirectly reducing the interest of foreign investors to seek investment in Indonesia.

b) Investment-Related Regulatory Restrictions

Regulatory restrictions on foreign investment are implemented by most countries to provide protection for the interests of their citizens against foreign interests. But regulatory restrictions also run the risk of hindering a country's FDI growth rate. According to data from the OECD in 2018, Indonesia is the third highest country for regulatory restrictions on investment, as can be seen from the graph below.

${ }^{48}$ Article 5 (2) The Act Number 25 of 2007 concerning Capital Market.

${ }^{49}$ Agus, Op.Cit, p. 30. 


\section{FDI Restrictiveness Index, 2018}

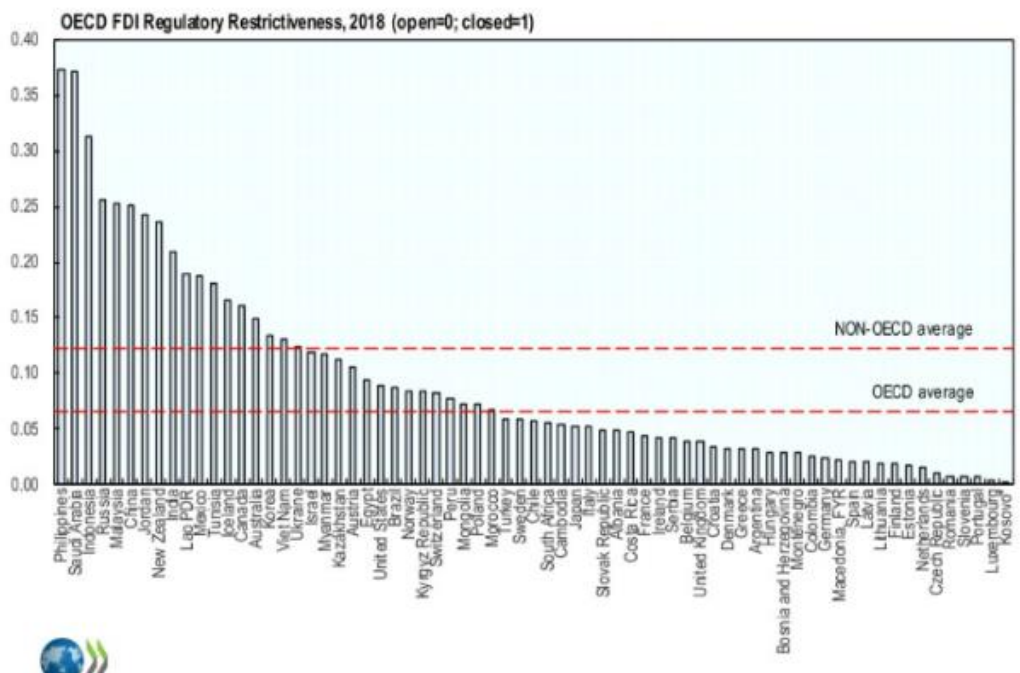

Figure 1: FDI Restrictions Index 2018

\section{FDI restrictions vary across sectors, 2018}

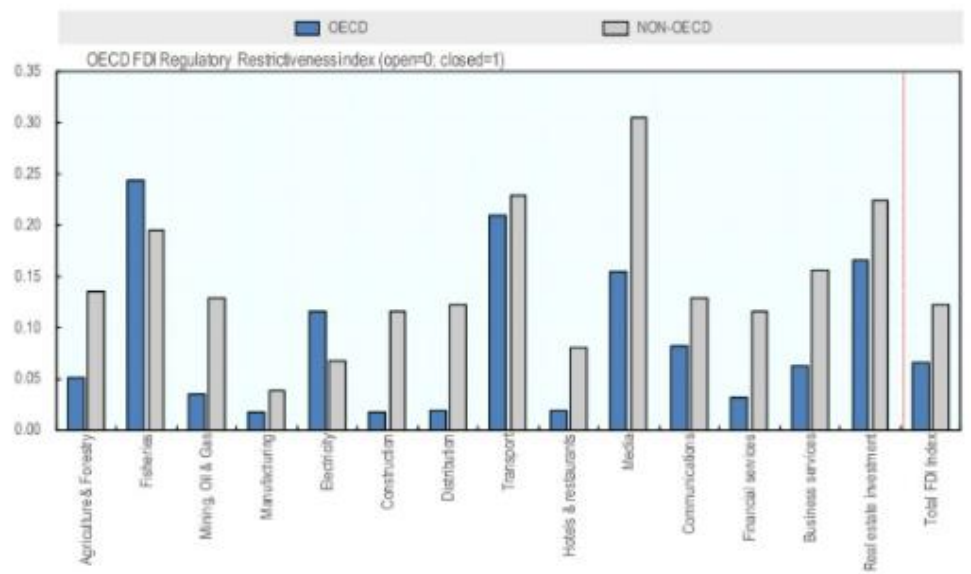

Figure 2: Restrictions on FDI Sector ${ }^{50}$

Based on the two graphs above, it shows that Indonesia has regulations that are restrictive to foreign investment practices. The OECD also explained that in general, regulatory restrictions on FDI are quite high in non-OECD countries, one of which is Indonesia. The related sectors, among others, are: plantation, fishery, gas and oil mining, transportation, electricity, media, and so on.

${ }^{50} \mathrm{OECD}$, “OECD FDI Regulatory Restrictiveness Index", OECD, 2020, accessed from http://www.oecd.org/investment/fdiindex.htm. 
c) Low Trust of Foreign Investors in Indonesia's Dispute Resolution System

Based on Article 32 (3), it explains that in the event of a dispute between the government and foreign investors, the dispute settlement will be carried out through international arbitration. ${ }^{51}$ However, this article does not explain how to resolve disputes between domestic private parties and foreign investors. However, according to the author's understanding, private dispute resolution can be carried out in accordance with the agreement of the parties, because it is flexible and agrees with the principle of freedom of contract. This is also in accordance with Article 3 of The Act Number 30 of 1999 concerning Arbitration and Dispute Resolution which states that the dispute settlement through arbitration must have an agreement between the two parties. Thus, the authors conclude that the main element is the agreement and the desire of the parties to settle the dispute. ${ }^{52}$ So, it's no wonder that foreign investors prefer to use foreign arbitration services, such as: SIAC, CIETAC, the Hong-Kong International Arbitration Center or the International Center for Settlement of Investment Disputes. In addition, investors choose other judicial jurisdictions to examine arbitration awards, such as: British Courts or Singapore Courts.

\section{Analysis of Protection Guarantee and Legal Certainty of Foreign Investors Against FDI Practices}

Responding to various problems with the practice of FDI in Indonesia, as previously explained. According to the author's understanding, foreign investors have been guaranteed legal protection both internationally and nationally. One of the guarantors is the World Trade Organization (WTO). This international institution issued the Principle of Non-Discrimination, which obliges the host country to provide equal treatment to foreign investors with domestic investors. ${ }^{53}$ Then, the principle of non-discrimination will be divided into two principles, among others: a) Most Favored Nation Treatment or the act of the host country to treat foreign investors the same as that given to investment from other foreign countries. b) National Treatment or providing foreign investors with the same treatment as domestic investors when operating in the same territorial area.

\footnotetext{
${ }^{51}$ Article 32 (3) The Act 25 of 2007 concerning Investment.

${ }^{52}$ Lydia Kaungang, "Penyelesaian Sengketa Penanaman Modal Menurut Undang-Undang Nomor 25

Tahun 2007", . Lex Pratioum, Volume 10, Number 6, 2017, p. 104.

${ }^{53}$ Dhaniswara K Harjono, Op.Cit., p. 153.
} 
The principles of the Word Trade Organization have been regulated in the Trade Related on Investment Measures (TRIMs) which was ratified by Indonesia in 1994 through Act Number 7 of 1994 concerning Ratification of the Agreement Establishing the World Trade Organization. ${ }^{54}$ In addition, the philosophy of the principle of non-discrimination has been applied by Article 3 (1) letter $\mathrm{d}$ of the Investment Law in relation to the principle of nondiscrimination, however there are inconsistencies in Article 62 regarding the provision of special behavior towards the state based on agreements between parties. This is not in accordance with the principle of non-discrimination of the WTO, besides that there is disharmony related to Article 1 point 4 with Article 5 (2) related to the form provisions of foreign investors. This inconsistency creates confusion among foreign investors as to which rules to choose. So that there is legal uncertainty.

Legal uncertainty due to inconsistency and disharmony of direct investment regulations has injured Article 14 letter a regarding the rights of investors to obtain legal certainty, rights and protection. According to the author's understanding, legal certainty is an essential element of a regulation. This was also revealed by Gustav Radburch that there are 3 principles of law called legal identity, including: 1) Principle of Legal Justice or gerectight, 2) Principle of Legal Certainty or rechmatigheid, 3) Principle of legal benefit or doelmatigheid. ${ }^{55}$ The three principles refer to the basic values of law. ${ }^{56}$

As a result, in 2021 the government issued Law Number 11 of 2020 concerning Job Creation which aims to eliminate overlapping rules, regulatory restrictions and facilitate licensing. However, according to the author's understanding, the formation of the Job Creation Law does not really affect the inconsistency of the article which creates discrimination against foreign investors.

In addition, based on the results of the OECD research in 2020, they explained that Indonesia was not the main destination for foreign investment, due to the large number of applicable regulatory restrictions, strong economic nationalism, the large role of $B U M N$, and a long bureaucratic process. ${ }^{57}$

\footnotetext{
${ }^{54}$ World Trade Organization, "Agreement on Trade Related Investment Measures", World Trade Organization, accessed from https://www.wto.org/english/tratop_e/invest_e/invest_info_e.htm\#: :text=The\%20Agreement\%20on \%20Trade-Related,which\%20violate\%20basic\%20WTO\%20princi.

${ }^{55}$ Sidik Sunaryo and Shinta Ayu Purnamawati, "Paradigma Hukum Yang Benar dan Hukum Yang Baik (Perspektif Desain Putusan Hakim Perkara Korupsi di Indonesia)", Triurnal Lemilit Trisakti, Volume 1, Number 2, 2019,.p. 2.

${ }^{56}$ Satjipto Rahardjo, Ilmu Hukum, Citra Abadi, Bandung, 2012, p. 19-20.

${ }^{57} \mathrm{OECD}$, "Investment Policy Review: Indonesia", OECD, 2020, accessed from https://www.oecdilibrary.org/finance-and-investment/oecd-investment-policy-reviews-indonesia-2020_b56512da-en.
} 
Thus, the authors suggest reviewing the investment law, especially in relation to the principle of non-discrimination against foreign investors, equity restriction on investment sector regulations, reforming the judicial system and resolving Indonesian disputes.

\section{CONCLUSION}

Indonesia is a country that has a myriad of natural and human resource potentials. This potential is sufficient to attract foreign investors to invest in Indonesia. However, in practice Indonesia's foreign direct investment inflows are not quite smooth compared to other Southeast Asian countries, such as: Malaysia, Vietnam, Thailand, Singapore. The growth of interest in FDI in the last 3 years has also decreased. The decline in the rate of FDI in Indonesia was influenced by several factors from a political, economic and legal perspective. This creates various problems with the protection rights of foreign investors in investing in Indonesia, including: The inconsistency of articles in the investment regulation injures the WTO's non-discrimination principle and guarantees the protection and legal certainty of foreign investors. In order to create legal certainty for foreign investors, it is necessary to conduct a review of the investment law, carry out equity restriction and reform the judicial system and resolve Indonesian disputes.

\section{DECLARATING OF CONFLITING INTEREST}

None

\section{FUNDING INFORMATION \\ None}

\section{ACKNOWLEDGEMENT}

In this case, the authors would like to thank Allah SWT for giving His grace and gifts so that this paper can be completed on time. In addition, the author also wants to thank all those who have supported the writing of this journal article, including family, colleagues, lecturers at the Faculty of Law, Universitas Negeri Semarang who have provided motivation and knowledge to write. I understand this writing is far from perfect. But I hope that later this article can provide new knowledge for readers. 


\section{REFERENCES}

Andani, D. (2019). Tinjauan Hukum Investasi Dampak Judicial Review Undang-Undang Nomor 25 Tahun 2007 Tentang Penanaman Modal. Nurani Hukum: Jurnal Ilmu Hukum, 2 (2).

Anita. (2021). Jaminan Kepastian Hukum Berinvestasi Melalui Pendekatan Konsep Lawrence M Friedman Dalam Menghadapi ASEAN Economic Community (AEC). Jurnal Res Justitia: Jurnal Ilmu Hukum, 1 (1).

Ansari, Muhammad Insa. (2020). Omnibus Law Untuk Menata Regulasi Penanaman Modal. Jurnal Rechtsvinding 9 (1).

Badan Pusat Statistik. (November, 2020). "Agustus 2020: Tingkat Pengangguran Terbuka (TPT) sebesar 7,07 persen." Badan Pusat Statistik. $\begin{array}{lllll}\text { November } & 05 & 2020 . & \text { Accessed }\end{array}$ https://www.bps.go.id/pressrelease/2020/11/05/1673/agustus-2020-tkala-peng unemployment-terbuka--tpt--sebesar-7-07-persen.html\#: : text $=$ Total $\% 20 \% 20$ work $\%$ 20\% 20August, $\%$ 200\% 2C24\% 20percent $\%$ 20 points.

Bank Indonesia. Laju Inflasi di Beberapa Negara. Bank Indonesia. Accessed from https://www.bi.go.id/seki/tabel/TABEL9_2.pdf.

Benuf, Kornelius dan Muhamad Azhar. (2020). Metodologi Penelitian Hukum sebagai Instrumen Mengurai Permasalahan Hukum Kontemporer. Jurnal Gema Keadilan, 7 (1).

Bank Indonesia. "Monetary" Bank Indonesia. Accessed from https://www.bi.go.id/id/fungsi-utama/moneter/default.aspx.

Bunawan, Petra. (2017). Foreign Investment in Indonesia the Legal Aspects under the New Indonesian Investment Law. Dialogica Iuridica, 8 (2).

Gloria. (July 2017). "Sembilan Puluh Persen Kekayaan Alam Indonesia Belum Dieksplorasi". Universitas Gadjah Mada. July 17 2021. Accessed from https://www.ugm.ac.id/id/berita/14277-sembilan-puluh-persenkekayaan-alam-indonesia-belum-dieksariasi.

Hadijah Alaydrus. (December 2020). "BI: Posisi Investasi Asing di Indonesia Melambat di Kuartal III, Apa Sebabnya Ya?". Ekonomi Bisnis. December 23 2020. Accessed from https://ekonomi.bisnis.com/read/20201223/9/1334622/bi-posisi-in Investasi-asing-di-indonesia-melambat-di-kuartal-iii-apa-sebabnya-ya.

Handoyo. (September, 2020). "ICW menyebut ada 169 kasus korupsi sepanjang semester I 2020". Nasional Kontan. September 29 2020. Accessed from https://nasional.kontan.co.id/news/icw-menyebut-ada-169-kasuskorupsi-sepanjang-semester-i-2020.

Harjono, Dhaniswara K. (2007). Hukum Investasi. Jakarta: Raja Grafindo Persada. 
Hutahayan, Benny, et al. (2020). Investor Protection in Mining Law in Indonesia. Journal of Critical Reviews 7 (13).

Jemadu, Aleksius, et al. (2016). Kinerja Diplomasi Ekonomi: Evaluasi atas Perjanjian Perdagangan dan Investasi. Jakarta: Badan Pengkajian dan Pengembangan Kebijakan Kementerian Luar Negeri Republik Indonesia.

Johnson, Darrel R and Greita Anggraeni. (2020). Foreign Investment Review 2020. London: Law Business Researched.

Kartiko, Galuh, et al. (2020). Penerapan Omnibus Law di Bidang Investasi Sebagai Upaya Penyelesaian Regulasi Perizinan dan Harmonisasi Peraturan Perundang-Undangan. Prosiding Seminar Nasional Multidisiplin Ilmu Universitas Asahan.

Kaunang, Lydia. (2017). Penyelesaian Sengketa Penanaman Modal Menurut Undang-Undang Nomor 25 Tahun 2007. Lex Prativum 10 (6).

Kompas Staff. (January 2021) "Provinsi dengan Jumlah Penduduk Terbanyak". Kompas. January 24 2021. Accessed from https://money.kompas.com/read/2021/01/24/090600726/7-provinsidengan-jotal-penduduk-terbanyak-di-indonesia?page=all\#: :text=K Kementerian\%20Dalam\%20Negeri\%20(MinistryofHomeAffairs)\%20stat ed,(number\%20population\%20Indonesia\%202021)

Kurniati, Yati, et al. (2007). Determinants of FDI (Factors that Determine Foreign Direct Investment). Bank Indonesia Working Paper.

Mahmud, Peter. (2005). Metode Penelitian Hukum. Jakarta: Prenadamedia Group.

Muhammad Wildan. (January 2021). "Revisi Daftar Negatif Investasi, Pemerintah Rilis Draf Perpres Terbaru". DDTCNews. Jnauary 112021. Accessed from https://news.ddtc.co.id/revisi-daftar-negatif-in Investasipemerintah-rilis-draf-perpres-terbaru26876?page_y=2470.666748046875.

Nordea. "Foreign direct investment (FDI) in Indonesia". Nordea Trade Portal. Accessed from https://www.nordeatrade.com/en/explore-newmarket/indonesia/investment.

OECD. (2020). “Investment Policy Review: Indonesia". OECD. 2020. Accessed from https://www.oecd-ilibrary.org/finance-and-investment/oecdinvestment-policy-reviews-indonesia-2020_b56512da-en.

OECD. (2020). “OECD FDI Regulatory Restrictiveness Index”. OECD. 2020. Accessed from http://www.oecd.org/investment/fdiindex.htm. 
Pijo, Feibe Engeline and Isle Junita Melo. (2020). Legal Study on NonCommercial Risk Investment in Indonesia. Advances in Social Science, Education and Humanities Research.

Presidential Regulation Number 44 of 2016.

Putri, Resha Roshana, et al. (2018). Peringkat Arus Investasi Indonesia Dalam Kerangka ASEAN-China Free Trade Agreement (Perbandingan Dengan Singapura, Malaysia, Thailand dan Vietnam) Ditinjau Dari Prinsip Fair dan Equitable Treatment. Jurnal Hukum \& Pembangunan 48 (2).

Rahardjo, Satjipto. (2012). Ilmu Hukum. Bandung: Citra Abadi.

Riski, Muhammad Akbar. (2018). Kepastian Hukum Investasi Bagi Perusahaan Penanaman Modal Asing di Indonesia. Skripsi. Fakultas Hukum Univesitas Negeri Jember.

Rohendi, Acep. (2014). Prinsip Liberalisasi Perdagangan World Trade Organization. Padjadjaran Jurnal Ilmu Hukum, 1 (2).

Simbolon, Nanci Yosepin, et al. (2020). Perlindungan Hukum Bagi Penanaman Modal Asing (PMA) di Indonesia. Jurnal Darma Agung 28 (1).

Soekonto, Soerjono. (2015). Pengantar Penelitian Hukum. Depok: University of Indonesia.

Sunaryo, Sidik and Shinta Ayu Purnamawati. (2019). Paradigma Hukum Yang Benar dan Hukum Yang Baik (Perspektif Desain Putusan Hakim Perkara Korupsi di Indonesia) Trijurnal Lemilit Trisakti 1 (2).

Surachman, Agus. (2018). Kritik Terhadap Undang-Undang Nomor 25 Tahun 2007 Tentang Penanaman Modal (Perspektif Teori Hukum). Unifikasi : Jurnal Ilmu Hukum.

Susanti, Rina. (2018). Peran Pertumbuhan Ekonomi dan Inflasi Terhadap Kinerja Investasi Asing Langsung (FDI) DI Negara ASEAN. Journal of Residues 2 (12).

The 1945 Constitution.

The Act Number 25 of 2007 concerning Capital Investment.

The Global Economy. Indonesia: Inflation. "The Global Economy". Accessed from

https://www.theglobaleconomy.com/Indonesia/inflation/\#: :text=The\%2 0average $\% 20$ value $\% 20$ for $\% 20$ Indonesia,on $\% 20$ countries $\% 20$ is $\% 200.0 \% 2$ 0percent.

Tirta Citradi. (September, 2020). “RI Masih Belum Ramah Investor Asing, Ini Buktinya". CNBC Indonesia. September 09 2020. Accessed from https://www.cnbcindonesia.com/news/20200904145710-4-184465/rimasih-belum-ramah-investor-asing-ini-buktinya.

Widyawan and Partners, Linklaters. (July, 2014). "Legal Guide to Investment in Indonesia". Widyawan and Partners. July 2014. Accessed from 
https://widyawanpartners.com/english/pubs/Investing-inIndonesia.pdf.

Winata, Agung Sudjati. (2018). Perlindungan Investor Asing dalam Kegiatan Penanaman Modal Asing dan Implikasinya terhadap Negara. Adjukasi: Jurnal Ilmu Hukum, 2 (2).

World Trade Organization. "Agreement on Trade Related Investment Measures". World Trade Organization. Accessed from https://www.wto.org/english/tratop_e/invest_e/invest_info_e.htm\#: :tex $\mathrm{t}=$ The $\% 20$ Agreement $\% 20$ on $\% 20$ Trade-

Related,which\%20violate\%20basic\%20WTO\%20princi.

Zakariya, Hafid. (2016). Pengaruh Hukum dan Politik Terhadap Perkembangan Investasi Asing di Indonesia. Jurnal Serambi Hukum 10 (2). 


\section{ABOUT AUTHOR(S)}

Januari Nasya Ayu Taduri, a woman born in Kudus, Central Java on January 17, 2000, is a student of the Faculty of Law, State University of Semarang. On campus, she is active in several activities. The organizations and student activity units that were participated in were: Head of Education Training English Discussion Community 2020, Member of the Scientific Work Division of Lex Scientia 2020, Journal Manager of the Editorial Section of Lex Scientia Law Review 2020, Members of the Litigation and Non-Litigation Section of the Private Commercial Law Community. 2021. In addition, she also participated in several off-campus activities, such as: Delegation at the Global Goals Model United Nations Kuala Lumpur Malaysia 2019, and Delegation at the International Model Nations Hanoi Vietnam 2019. 